\title{
Forest Tent Caterpillar, Malacosoma disstria Hübner (Insecta: Lepidoptera: Lasiocampidae) ${ }^{1}$
}

James R. Meeker ${ }^{2}$

\section{Introduction}

The forest tent caterpillar, Malacosoma disstria Hübner, is the most widely distributed indigenous tent caterpillar in North America (Furniss and Carolin 1977). The forest tent caterpillar has been recognized as an important defoliator of a wide variety of deciduous hardwood trees throughout its range for many years (Batzer and Morris 1978). Although this univoltine insect is called a tent caterpillar, it is unlike other Malacosoma species in that the larvae do not construct tents. Instead, forest tent caterpillars spin silken mats on the trunks and large branches where they congregate to molt or rest from feeding. Larvae also deposit silk in strands along which they travel to and from feeding sites. The caterpillars themselves are relatively harmless to people (i.e., they do not bite or sting) although a few people have an allergic reaction to handling them.

Populations of forest tent caterpillars occasionally or periodically attain outbreak proportions. During outbreaks, enormous numbers of caterpillars cause widespread and extensive defoliation of host trees, and may create an overwhelming nuisance to people encountering them. Except in southwest Alabama and southern Louisiana where abundant populations recur annually on water tupelo, Nyssa aquatica L. (Batzer and Morris 1978), the forest tent caterpillar is elsewhere considered as one of the cyclical outbreak species among forest Lepidoptera (Myers 1993). Populations of forest tent caterpillar characteristically fluctuate between extremes on a somewhat regular schedule, typically increasing to outbreak proportions every six to 16 years (Myers 1993; USDA Forest Service 1996). Outbreaks usually subside after two to four years of heavy defoliation, but have persisted for up to six years (USDA Forest Service 1996). Seldom are trees killed during such outbreaks and where tree mortality has occurred, it usually has not been substantial (Anderson 1960). Severe and repeated defoliation can, however, lead to dieback and/or reduced growth of affected trees, which in some instances may be significant (Drooz 1985).

One of the earliest documented forest tent caterpillar outbreaks in Florida occurred in Citrus and Marion counties during the Aprils of 1965 through 1967. The outbreak was noted as widespread (ca.

1. This document is EENY-184 (originally published as DPI Entomology Circular 385), one of a series of Featured Creatures from the Entomology and Nematology Department, Florida Cooperative Extension Service, Institute of Food and Agricultural Sciences, University of Florida. Published: January 2001. This document is also available on Featured Creatures Website at http://creatures.ifas.ufl.edu. Please visit the EDIS Website at http://edis.ifas.ufl.edu.

2. James R. Meeker, Florida Department of Agriculture and Consumer Services, Division of Plant Industry, Gainesville, FL.

The Institute of Food and Agricultural Sciences (IFAS) is an Equal Employment Opportunity - Affirmative Action Employer authorized to provide research, educational information and other services only to individuals and institutions that function without regard to race, creed, color, religion, age, disability, sex, sexual orientation, marital status, national origin, political opinions or affiliations. For information on obtaining other extension publications, contact your county Cooperative Extension Service office. Florida Cooperative Extension Service / Institute of Food and Agricultural Sciences / University of Florida / Larry R. Arrington, Interim Dean 


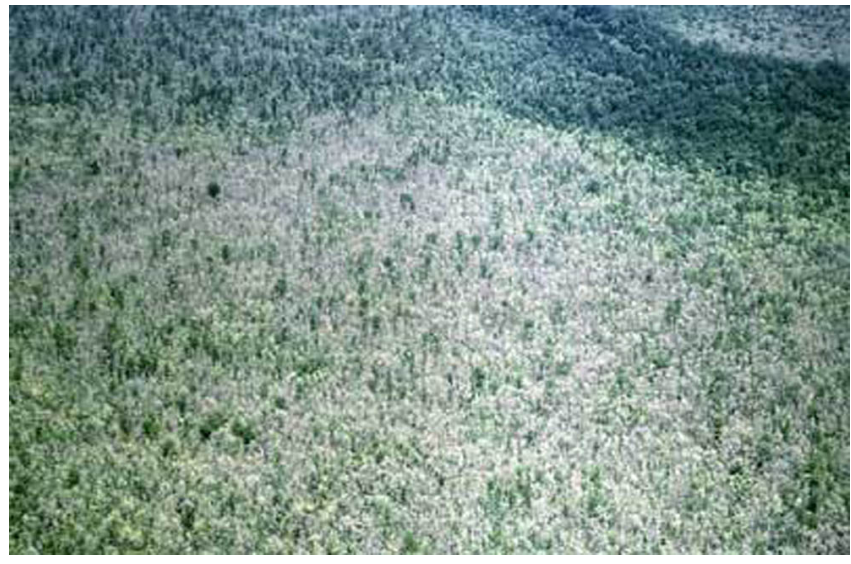

Figure 1. Forest showing an outbreak of the forest tent caterpillar, Malacosoma disstria Hübner, with resulting defoliation. Credits: Charles W. Chellman, FDACS, Division of Forestry

$30,000 \mathrm{ac}$ ), causing very heavy defoliation of turkey oaks (Quercus laevis Walter) and a "great problem" due to the abundance of crawling caterpillars. Other large forest tent caterpillar outbreaks in Florida have been recorded in Pasco County (1967; ca 2,000 affected acres; primary host turkey oak), Citrus and Hernando counties (1969; ca 10,000 ac of the Withlacoochee State Forest; turkey oak), Hernando, Marion and Pasco counties (late March to April 1977; ca 25,000 acres; turkey oak), and Hernando, Lafayette, Levy and Pasco counties (1988; Quercus spp.) (Florida Department of Agriculture and Consumer Services, Division of Plant Industry (FDACS-DPI) and Division of Forestry (DOF) records).

More recently, outbreak populations of forest tent caterpillar and its associated problems have reached unprecedented heights in West Central Florida. Noticeable levels of defoliation were first reported in portions of Polk and Hillsborough counties on water oak (Quercus nigra L.), laurel oak (Q. laurifolia Michaux), and live oak ( $Q$. virginiana Miller), during the spring of 1993. Outbreaks of forest tent caterpillar have since developed on the same hosts in many of the surrounding areas of Citrus, DeSoto, Hardee, Hernando, Highlands, Lake, Manatee, Pasco, Pinellas, Orange, Osceola, and Sarasota counties. The extent, magnitude and impact of this outbreak reached pronounced levels in 1995 and, in general, escalated to alarming proportions in 1997. Noticeable declines in forest tent caterpillar populations were, however, recently evident at some locales where caterpillars had been abundant for three to four years. Although no tree mortality has occurred as a direct result of defoliation, the sheer number of caterpillars, their frass, and the subsequent populations of adult moths have caused numerous problems for people, particularly in urban environments.

\section{Distribution}

The forest tent caterpillar is found throughout most of the United States and southern Canada, but is more common cast of the Mississippi River. Its occurrence roughly corresponds to the ranges of its host trees. Records of FDACS-DPI and DOF have reported Forest tent caterpillar in the following counties: Alachua, Baker, Bay, Citrus, Dade, DeSoto, Duval, Hardee, Hernando, Highlands, Hillsborough, Indian River, Lafayette, Lake, Leon, Levy, Liberty, Madison, Manatee, Marion, Orange, Osceola, Pasco, Pinellas, Polk, Sarasota, Sumter, Taylor and Volusia. Despite no known records of forest tent caterpillar in 38 of Florida's 67 counties, Forest tent caterpillar probably occurs, or could exist, virtually anywhere in Florida, given the statewide distribution of known host trees.

\section{Description}

Larvae have a dark-gray to brownish-black background body color, highlighted by broad, paleblue lines and thin, broken yellow lines extending along each side. On the dorsum of each abdominal segment is a distinct whitish keyhole or shoeprint-shaped marking. Larvae are also somewhat hairy, the setae being fine, whitish in color, and sparsely distributed. Mature larvae are 2 to 2.5 in. (50 to $64 \mathrm{~mm}$ ) in length. Dixon and Foltz (1991) provide color photos and comparisons with other common or important forest caterpillars. Pupation occurs in a pale- yellow, loosely spun silken cocoon. The stout-bodied adult moths are tan to buff-brown in color, with two darker, thin parallel lines extending across the mid-portion of each forewing, the area between often being dark and appearing as a single, broad, dark band. The wingspread ranges from 1 to 1 $3 / 4$ in. (25-45 mm). Eggs occur in masses of 100 to 350 , forming bands up to 1 in. $(25 \mathrm{~mm})$ in length that encircle small diameter twigs. Egg masses are coated 
with a dark-brown, frothy, cement-like substance called spumaline (Anderson 1960; Drooz 1985).

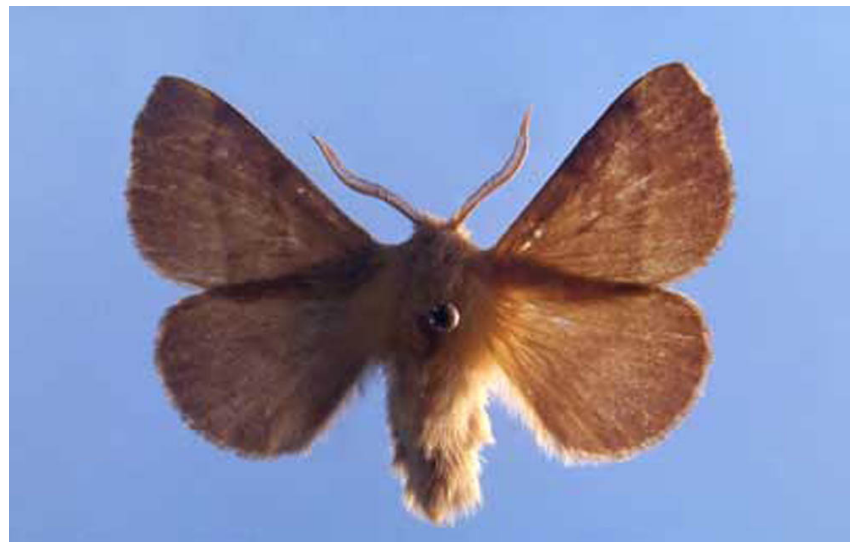

Figure 2. Adult forest tent caterpillar, Malacosoma disstria Hübner. Credits: Jeffrey Lotz, Division of Plant Industry

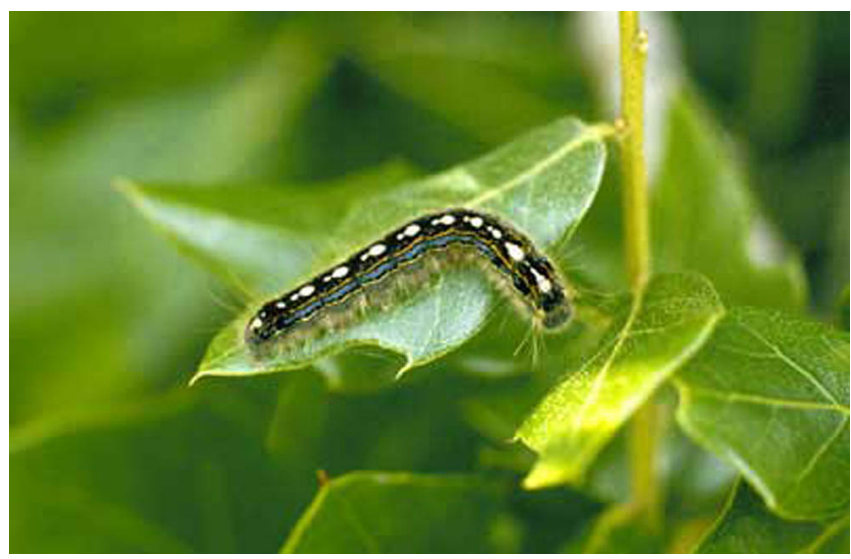

Figure 3. Dark color phase larva of the forest tent caterpillar, Malacosoma disstria Hübner. Credits: James R. Meeker, FDACS, Division of Forestry

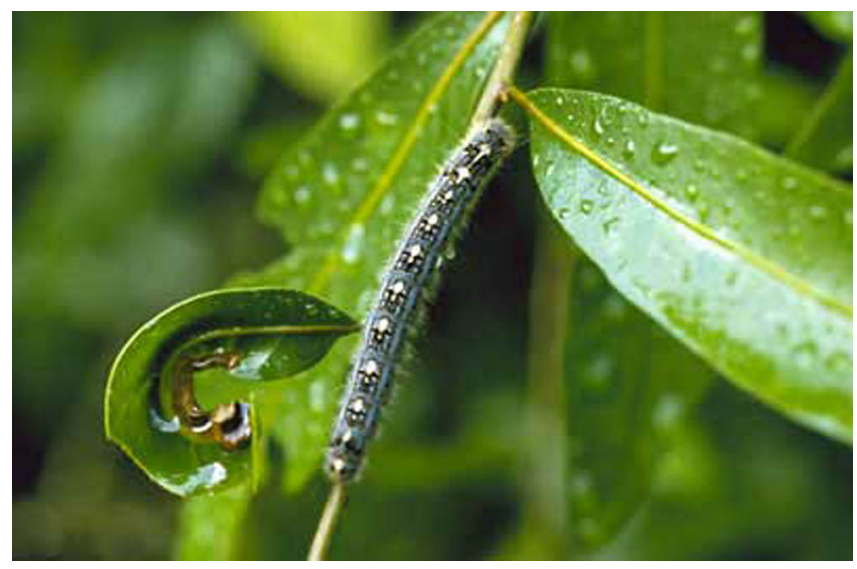

Figure 4. Light color phase larva of the forest tent caterpillar, Malacosoma disstria Hübner. Credits: Wayne Dixon, Division of Plant Industry

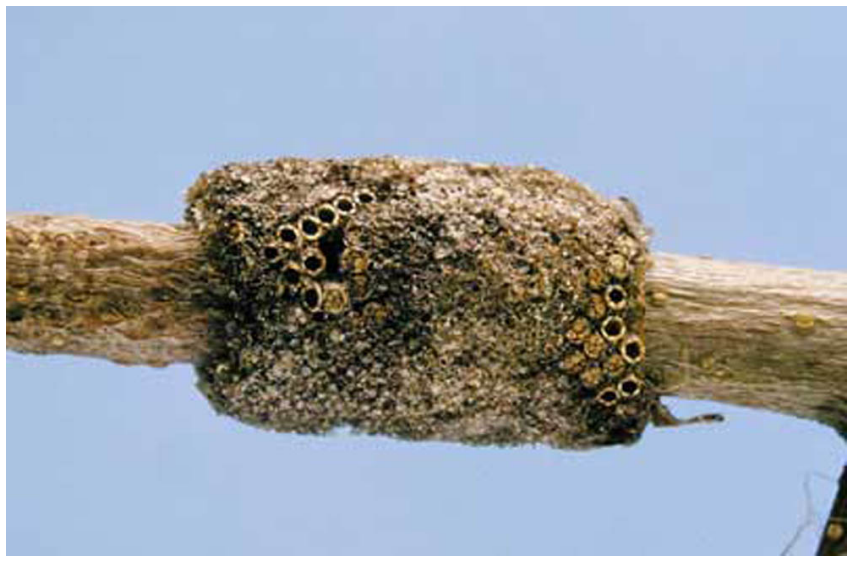

Figure 5. Typical egg mass of the forest tent caterpillar, Malacosoma disstria Hübner. Credits: Jeffrey Lotz, Division of Plant Industry

\section{Biology}

The forest tent caterpillar has only one generation per year throughout its range. Overwintering larvae within egg masses begin emerging in early spring concurrent with the swelling and expanding of buds on host trees. In Florida, mass hatching of eggs commonly peaks during March, but has been observed as early as mid-February and as late as April. The young larvae are gregarious and initially feed together on the expanding buds, foliage, and flowers. As forest tent caterpillars develop through five larval instars, they eventually devour entire leaves. Late instar larvae tend to wander, individually traveling within, among or out of host trees, either in search of additional food or a place to pupate. It is during the two to six weeks when caterpillars are noticeably present, particularly when they are approaching maturity, that the resulting circumstances create adverse situations for people, i.e., unpleasant encounters with caterpillars and their droppings. The pale-yellow pupal cocoons are variously located amongst webbed leaves, bark crevices, shrubbery and other somewhat protective places such as on the sides and under overhangs of buildings. Pupation takes 10 to 14 days, after which the adult moths emerge, mate and females oviposit egg masses on host trees. Although adult moths do not feed and live for only two to 10 days, they can create considerable nuisances when congregating in abundance around nighttime lighting. In Florida, adults may be expected to emerge sometime between April and late-May, but have been collected as early as February (J.B. Heppner, personal 
communication). Within egg masses, pharate larvae develop by fall and diapause through winter until emerging the following spring to begin the cycle again.

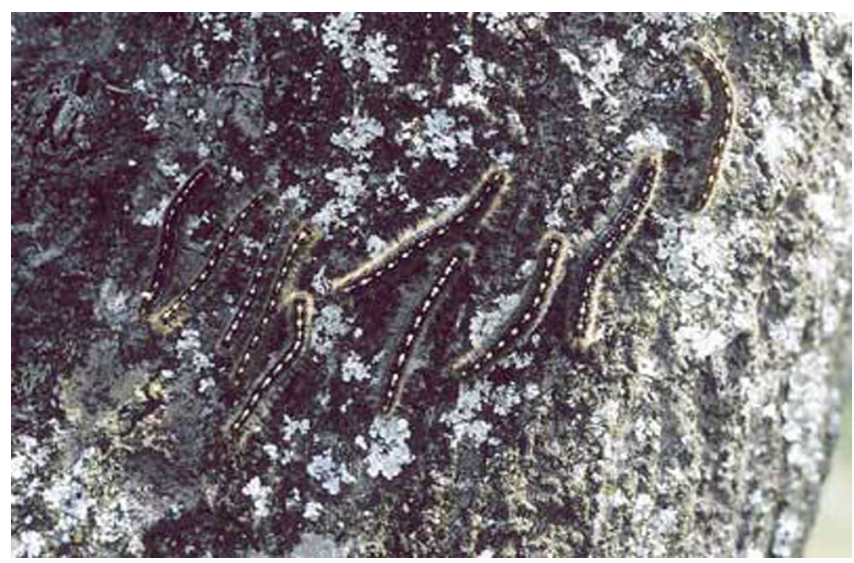

Figure 6. Gregarious larvae of the forest tent caterpillar, Malacosoma disstria Hübner. Credits: James R. Meeker, FDACS, Division of Forestry

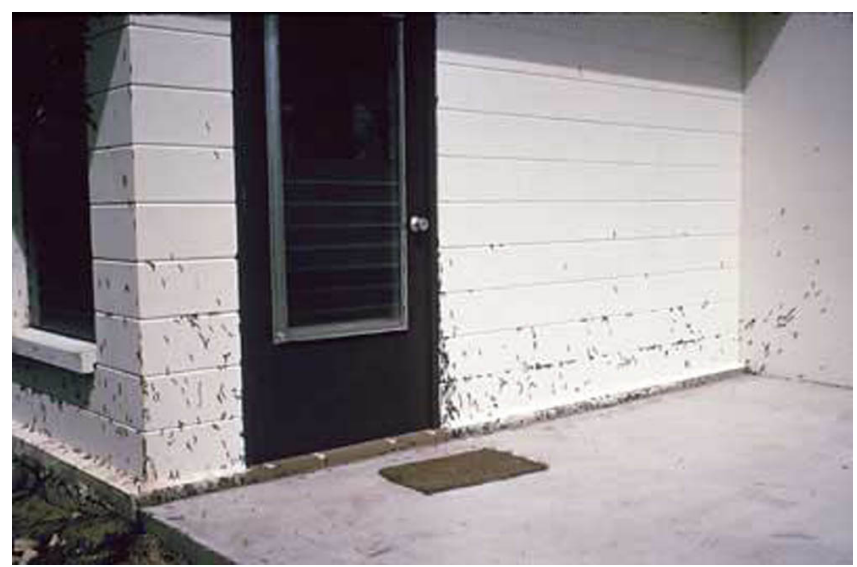

Figure 7. Larvae of the forest tent caterpillar, Malacosoma disstria Hübner, seeking sites for pupation on the side of a structure. Credits: James R. Meeker, FDACS, Division of Forestry

\section{Host Plants}

In the southern United States, the preferred hosts which are most heavily defoliated include various species of oaks (Quercus spp.) and gums (Nyssa spp. and Liquidambar styraciflua L.). Other common or occasional hosts in the South include basswood (Tilia americana L.), cherry (Prunus spp.) and plum (Prunus spp.). In the northern and western U.S. and Canada, trembling aspen (Populus tremuloides Michx.) is the preferred host. Large larvae during outbreaks will, however, feed on a wide variety of deciduous hardwood trees and some unusual hosts including conifers. For example, during the recent outbreak in West Central Florida, forest tent caterpillars were observed feeding on virtually all sorts of woody plant foliage, some of which included citrus (Citrus sp.), pine (Pinus sp.), loquat (Eriobotrya japonica Lindl.), azalea (Rhododendron sp.), and rose (Rosa spp.). If otherwise healthy, the common host trees will typically refoliate within a few weeks, after the springtime defoliation.

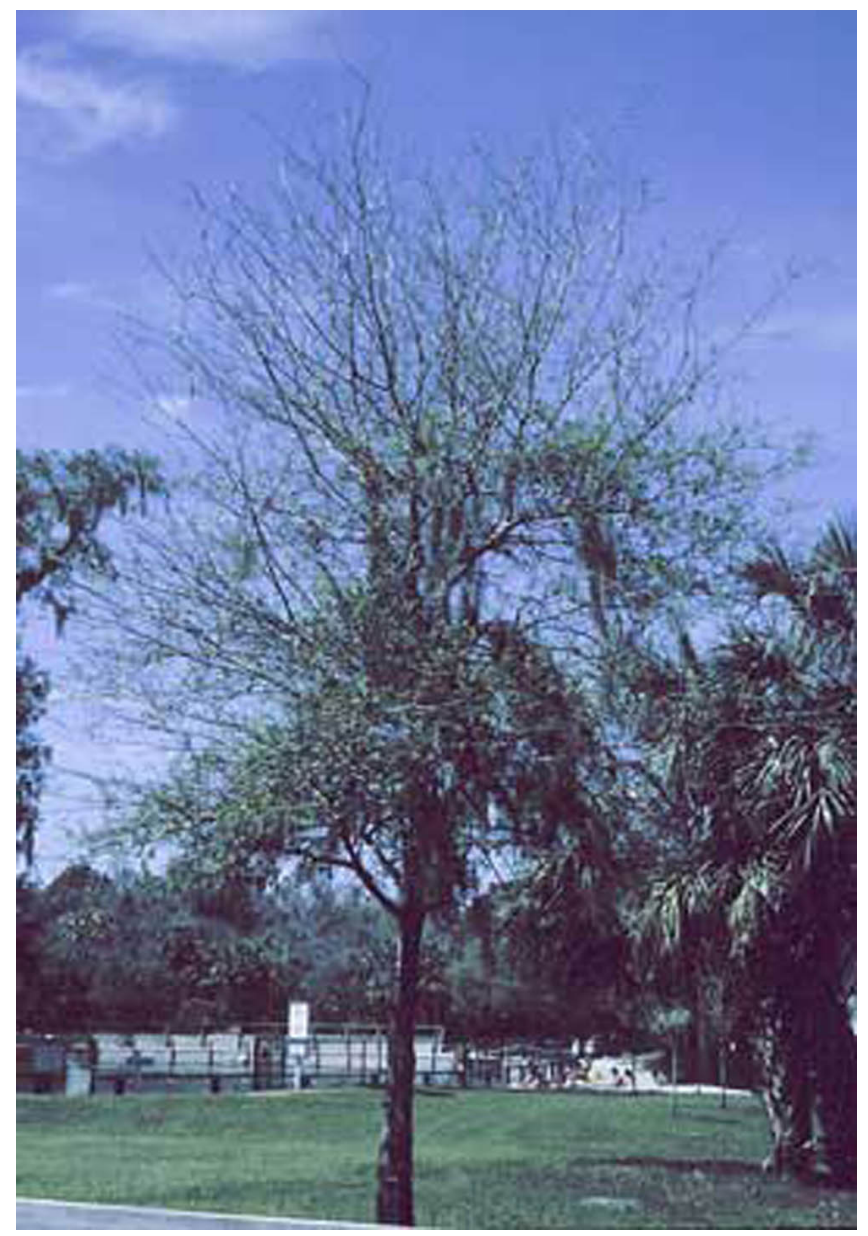

Figure 8. Tree defoliated by larvae of the forest tent caterpillar, Malacosoma disstria Hübner. Credits: James R. Meeker, FDACS, Division of Forestry

\section{Natural Controls}

A wide variety of factors have been implicated in causing population declines, including several adverse environmental conditions. High levels of larval mortality have been associated with relatively low temperatures in the winter and spring (such as a late or hard freeze following larval emergence) and harsh weather when early instars are abundant. Harsh weather and extremely high temperatures may kill 
numerous adults later in the spring, and also reduce mating success and viability of offspring amongst survivors. Outbreak populations may also decline or collapse as a result of starvation, when larvae exhaust food supplies (i.e., host foliage) before completing development (Drooz 1985).

Natural enemies such as parasites, predators, and diseases may also exert important regulatory effects on Forest tent caterpillar populations. Some natural enemies are often extremely abundant during the later stages of outbreaks (Drooz 1985). The documented natural enemies of tent caterpillars are numerous, including 14 species of Hymenoptera egg parasites, 52 Diptera and 61 Hymenoptera species parasitic of larval and pupal stages, and 18 Hemiptera, nine Coleoptera and one Dermaptera that are predators of various life stages (Witter and Kuhlman 1972). At least 18 species of the parasitic insects have been recorded in Florida (Frank and Foltz 1997), as well as a parasitic nematode in the family Mermethidae.

Other known predators include frogs, mice, skunks and over 60 species of birds (Witter and Kuhlman 1972). Bird predation of late-instar and pupal stage forest tent caterpillars has recently been demonstrated to cause overwhelming mortality of populations at all densities in an artificial setting, and is hypothesized as the principle regulator of low density populations between outbreaks (Parry et al. 1997).

Forest tent caterpillars are also susceptible to a variety of diseases that may be caused by viral, fungal, protozoan or bacterial organisms, occurring alone or in combination naturally. All four types of disease have been diagnosed in forest tent caterpillar larvae from Florida (D.G. Boucias, personal communication). Epidemic proportions of a nuclear polyhedrus virus (NPV) have often been observed killing enormous numbers of caterpillars a few years after the beginning and during the decline of forest tent caterpillar outbreaks. Caterpillars killed by NPV are characteristically found hanging in place from their midsection, appearing like an inverted "V". Infected larvae may also appear sluggish, and upon dying, turn darker in color and wilt. This and other host specific NPV's have recently been suggested as the driving force responsible for regulating the cyclical populations of tent caterpillars (Myers 1993). The host specificity, environmental safety, and effectiveness of the NPV make it an excellent candidate for a potential bioinsecticide in the future, but currently this work is not being pursued (Frank and Foltz 1997; Myers 1993).

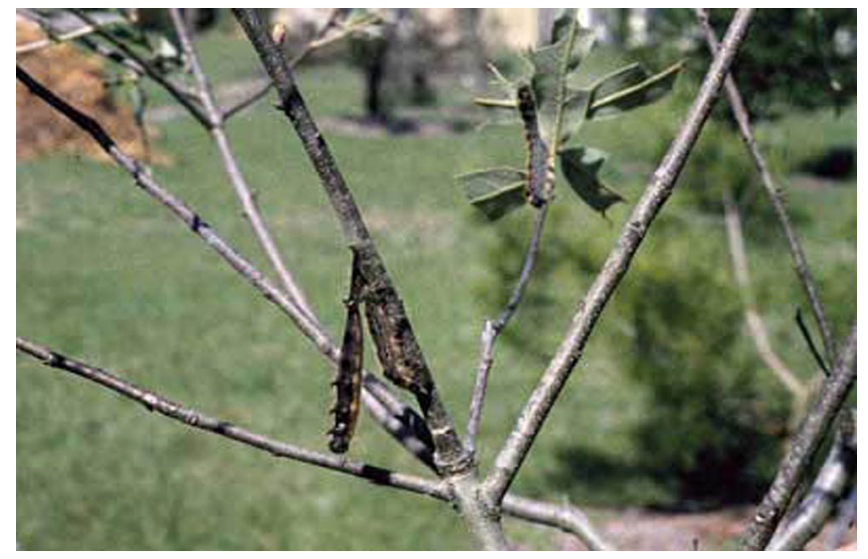

Figure 9. Larva of the forest tent caterpillar, Malacosoma disstria Hübner, killed by a nuclear polyhedrus virus and exhibiting the characteristic symptom of hanging in place from its midsection, appearing like an inverted "V." Credits: James R. Meeker, FDACS, Division of Forestry

\section{Management Recommendations}

Outbreaks or the regular population cycles of forest tent caterpillars are apparently extremely difficult to manipulate or control (Myers 1993). Couple this with the fact that repeated outbreaks have not caused any seriously devastating impacts to host trees, and area wide control efforts are seemingly cost prohibitive, potentially futile and, most importantly, unwarranted. At a residential level, even if successful caterpillar control is temporarily achieved with an insecticide, caterpillars will often readily migrate in from surrounding untreated properties. There is also no practical way to prevent adult moths from locating host trees and depositing the egg masses of next year's caterpillars. Beyond simply learning to accept and tolerate the inevitable encounters and defoliation during these cyclical outbreaks, there are some measures which may provide some relief or reduce the impact when populations reach unacceptable thresholds.

A practical approach is to avoid the caterpillars and their frass as much as possible, such as by refraining from outdoor activities during times and at places where forest tent caterpillars are abundant. 
Other means of avoidance include not parking under infested trees, keeping unnecessary outdoor lighting off when adults are present, and keeping windows and doors closed or tightly screened.

Populations of forest tent caterpillars and resulting defoliation can be temporarily reduced by various methods of direct control. However, the following direct control measures are only recommended for cases where tree health is jeopardized by defoliation or the nuisance of Forest tent caterpillar is intolerable. A preventive and least toxic approach is to prune out and destroy all twigs bearing egg masses prior to caterpillar emergence. This is best accomplished in the winter after most of the leaves have fallen and egg masses are readily visible. Just prior to or following caterpillar emergence, tree trunks can be banded with a stickem, such as Tanglefoot, which will trap wandering caterpillars and prevent them from ascending and descending trees, thereby restricting their movements and reducing their numbers. The caterpillars can also be killed with any number of insecticides registered for such use.

When using an insecticide preferably target young caterpillars before they begin widespread wandering and prior to problems with frass and defoliation becoming evident. Insecticides containing Bacillus thuringiensis (a bacterium) or diflubenzuron (an insect growth regulator) as the active ingredient are only toxic (at label rates) to immature insects and then only through ingestion. These materials are therefore likely to be much less harmful to non-target organisms than conventional insecticides. Despite the relative specificity and effectiveness of Bacillus thuringiensis and diflubenzuron insecticides, both are relatively slow-acting and can have negative effects on non-target caterpillars, such as butterflies. Consult your local county agricultural extension office for current insecticide recommendations. If choosing to use insecticides, carefully read and follow label directions. During and after episodes of severe defoliation, promote tree health and vigor to aid its recovery. One direct control measure worth avoiding includes attempts to brush off, squash or smash caterpillars and pupae. This approach has little or no impact on populations and most often results in a very difficult to remove stain.
Insect Management Guide for Landscape Plants

\section{Selected References}

Anderson, R.F. 1960. Forest and shade tree entomology. John Wiley \& Sons, Inc. New York, NY. 428 p.

Batzer, H.O., and R.C. Morris. (1978). Forest Tent Caterpillar. U.S. Department of Agriculture, Forest Service, Forest Insect \& Disease Leaflet 9. http://willow.ncfes.umn.edu/fidl-ftc/tentcat.htm (31 December 2000).

Dixon, W.N., and J.L. Foltz. 1991. Caterpillars that are not the gypsy moth caterpillar. Some forest Lepidoptera in Florida (Lepidoptera: Arctiidae, Lasiocampidae, Lymantriidae). Florida Department of Agriculture \& Consumer Services, Division of Plant Industry, Gainesville, FL. Entomology Circular No. 270.2 p.

Drooz, A.T. (ed.). 1985. Insects of eastern forests. U.S. Department of Agriculture, Forest Service, Washington, D.C. Miscellaneous Publication 1426. $608 \mathrm{p}$.

Frank, J.H., and J.L. Foltz. 1997. Classical biological control of pest insects of trees in the southern United States: a review and recommendations. U.S. Department of Agriculture, Forest Service, Forest Health Technology Enterprise Team, Technology Transfer, Biological Control. Morgantown, WV. FHTET-96-20. 78 p.

Furniss, R.L., and V.M. Carolin. 1977. Western forest insects. U.S. Department of Agriculture, Forest Service, Washington, D.C. Miscellaneous Publication 1339. $654 \mathrm{p}$.

Myers, J.H. 1993. Population outbreaks in forest Lepidoptera. American Scientist 81: 240- 251.

Parry, D., J.R. Spence, and W.J.A. Volney. 1997. Responses of natural enemies to experimentally increased populations of forest tent caterpillar, Malacosoma disstria. Ecological Entomology 22: 97-108.

U.S. Department of Agriculture, Forest Service. 1996. Pest Alert: Forest Tent Caterpillar. U.S. 
Department of Agriculture, Forest Service,

Northeastern Area and Region 8. NA-PR-02- 96. 1 p.

Witter, J.A., and H.M. Kuhlman. 1972. A review

of the parasites and predators of tent caterpillars

(Malacosoma spp.) in North America. Minnesota

Agricultural Experiment Station. Technical Bulletin

289. $48 \mathrm{p}$. 